8

\title{
Take and Eat: Eve, Mary, and Feminist Christianity
}

\author{
Martha Kalnin Diede
}

In current critical discussions, much ink covers women's bodies, and much of this discussion centers on the ways in which women's bodies are constructed by the phallocentric language that writers use to describe them. Indeed, the literary history of women's bodies in language has problematized pregnancy, lactation, menstruation, and sexual desirability. Critical discussion includes Bynum's study of medieval women and food in Holy Feast, Holy Fast (1987), Bell's examination of Italian saints in Holy Anorexia (1985), extended discussions of female mystics, and discussions of individual works, such as Laura Esquivel's Like Water. for Chocolate and Toni Morrison's Beloved. Yet few theorists have addressed the connection between women and food as a widespread literary phenomenon (Magid, 2008; Heller and Moran, 2003). The persistent comparison of women to Eve or to Mary - and women's position between the two examples - is now commonly recognized in feminist thinking (Williams and Echols, 1994). Although Eve's sin was appetite and Mary's virtue was (sexual) abstinence, most considerations of women and their bodies relate in some way to the sexual: early feminists argue for female capability to do much more than produce children (see the introduction to Freedman, 2007), and second and third wave feminists argue for separate study of women's bodies and experiences. ${ }^{1}$ While important lines of inquiry, these kinds of scholarship point to reproductive function as a touchstone, and such an approach deserves reconsideration. Instead of focusing on the sexual nature of Mary's virtue and its seemingly easy contrast to Eve's reckless eating, critics might reconsider the relationship between women, appetite, and food. Thinking of food as a location of female power and pleasure, the recognition of which has long been denied to women, scholars might offer new insights into the struggle that women historically have had (and many women still do have) with food and sustenance. 


\section{PROOF}

Theoretical considerations of food and appetite suggest revised understandings of the implications of Eve's original sin, the Last Supper, and Communion. God's commands in Genesis encouraged Adam and Eve to eat from every tree except one. Eve, then Adam, disobeyed this one command, choosing to eat the fruit of that forbidden tree. This story explicitly links eating with sin. The persistent associations between Eve and Adam's disobedience, appetite, and food have developed into associations between disobedience and any appetite, for example knowledge, power, money, or fame. Because of the frequent connection between appetite, disobedience, and sexuality, for women, eating is often connected with sexual promiscuity. The results of eating - fatness - or of not eating - thinness - are also loaded with cultural associations related to sexuality and/or sexual desirability. In addition to women's sexuality, their primary or secondary sexual characteristics, or their mouths with unruly tongues and voices, the food that enters the mouth and its functions merit attention. In its essence, Communion is a meal. So, Christ's insistence that his followers repeat this meal requires that people sit down to eat with one another and that eating is an important activity. In addition, although small, the portions of the symbolic meal are explicitly linked with satisfaction. No one at Christ's table leaves hungry or thirsty. Even more remarkable in the context of this discussion is the insistence upon eating itself as a way to remember salvation, instead of a way to remember temptation and fall. This fact itself radically redefines the act of eating as salvific rather than sinful. If eating is neither sinful nor sin-producing, then appetite is neither sinful nor sinproducing. For women, this shift is particularly important as it forces re-examination of the link between women, eating, and sin.

Critics and Christians need further to examine the activity of preparing, serving, and eating food, historically the province of women, as a site of female power. In fact, the ways in which women teach other women how to cook, how to serve, and how to eat may indeed imply a recognition of the threat that women's relationships to food pose to 'established order.' Thus, by determining that women's relationship to food is primarily one of sexual appetite rather than gustatory appetite, critics have ignored the potential for self-determination and power that the kitchen represents. For indeed, women prepare and serve. But they also eat. Moreover, Christians, all of whom eat and drink the sacrament of Communion, symbolically repeat and literally remember Christ's offering of his body and blood for salvation of sin. Scholars overlook the fact that Communion is an invitation to eat and to drink that also redeems Eve's original disobedient eating. For women, the act 


\section{PROOF}

of preparing, then eating - physically sustaining and salvific - becomes an act of presence: a way of being heard aloud rather than remaining silent, a way of becoming a subject rather than an object, and, in Communion, a way of being served rather than serving.

Because of the lengthy, complex relationship between women and food, any examination of this relationship benefits from a brief re-telling of the story: Adam and Eve in the Garden of Eden - Eve's eating, Adam's fall, and the accompanying curses; the corresponding story of redemption the Virgin Birth, the Last Supper, crucifixion, and resurrection. Essentially, the narrative begins when God creates light, dark, earth, water, plants, animals, and finally Adam. But Adam is unhappy alone. So God causes Adam to sleep, removes a rib, and makes Eve. Adam finds Eve to be a suitable companion, and they live happily in the Garden of Eden. Although God invites Adam and Eve to eat all of the fruits of the garden except one, Satan tempts Eve with precisely that fruit. Eve, falling to temptation, eats the fruit, and then offers it to Adam. Adam eats. Sin enters the world; God evicts Adam and Eve from the garden. God curses Adam with hard work and Eve with pain in childbirth, a curse that makes sense only if Eve and Adam are sexually active. Humans must now be redeemed. But, because both Adam and Eve participated in the fall, both Adam and Eve participate in the coming redemption. Millennia later, Christ will be the second Adam, and Mary, a virgin, a second Eve, will give Him birth. Nowhere in this story is Eve's sin related to $\operatorname{sex}^{2}$ While the curse that she suffers certainly results from sexual activity, sex and sexual desirability are not Eve's curses. Indeed, they are not Adam's curses either. The root of sin in the world is not eating itself or sex, but disobedience, explicitly linked to eating a forbidden food.

The story of redemption begins with God's procreation. An angel approaches Mary, a virgin, and tells her that she will become pregnant without sex. She will give birth to Jesus, who will save the world from sin and reverse the curse that Eve and Adam brought into the world. Mary agrees, and Christ is born. Thirty-three years later, Jesus and his disciples gather to eat. At the Last Supper, Jesus offers his disciples broken bread, commanding, 'This is my body given for you; do this in remembrance of me.' He then offers them a cup of wine, announcing 'This cup is the new covenant in my blood, which is poured out for you' (Luke 22:19-20; New Intemational Version). Significantly, Jesus interprets his coming crucifixion and resurrection as an act of eating and drinking and commands eating. At this table, eating becomes a mnemonic for two gustatory events: Adam and Eve's ingestion of the 


\section{PROOF}

fruit of the forbidden tree that brought sin into the world, and Christ's offering of himself as food for the disciples which brings redemption into the world.

Christians, however, have ignored the fact that the clear parallels between commands regarding the acts of ingestion - one bringing sin, the other bringing salvation - do not, in fact, point to sexual status as a particular measure of any state of soul. Under the influence of Jerome and Augustine, ${ }^{3}$ medieval theologians reinterpreted Eve's sin as appetite, specifically sexual appetite, in contrast to Mary's sexual abstinence. This despite the fact that sex does not appear at all in the narrative surrounding Christ's crucifixion and resurrection, nor in the insistence of the Last Supper on ingestion as a symbol of salvation. Still, by clearly deriving Mary's holiness from her virginal state, ${ }^{4}$ such thinking made easy the transfer of Eve's sinful disobedience from food to sex. Mary is holy because she is a virgin; Eve is cursed because she is not. The accretion of beliefs around Mary - that she and Joseph never consummated their marriage because he believed she was too holy, for example suggests that maintaining Mary's virginal state as a model for women placed women in society in a very difficult position. This thinking, however, consistently ignores the fact that sin entered the world as a result of disobedient ingestion on the part of both Eve and Adam.

Mary's pure state is unattainable for any other woman. As Wamer (1983) points out, Mary is 'alone of all her sex,' for she is the only woman to give birth to a sinless infant. Assigning women the blame for birthing both sin and sinful people makes every woman a new Eve. Men's sexual desire for women produces not only sin itself, but also more sinners. Woman becomes the object of desire, first as the difficult mate for the adult male, then as the nursing mother for the infant male. In both situations woman bears the responsibility for sin: first for generating sexual desire that she may or may not satisfy; then for having given birth to a sinful man who inhabits a difficult world. In essence, woman can satisfy neither the adult male's desire for sex nor the male infant's desire for sustenance. The conclusion, then, is that somehow she purposefully withholds more than temporary satisfaction. And, because she is Eve the incarnation of the archetypal woman - who brought sin and more people into the world, she is responsible. Thus sin, the force of evil in the world, becomes displaced from men and relocated in the female body alone. So, to deny the female body is also to deny sin. To deny the appetites of the female body is to deny sinful appetite. Furthermore, to control the female body is to control sin and to achieve a state of holiness that prepares one for heaven. And this persistent equation of 
temptation with the desires of and for the female body has led to the rejection of Eve's sinful appetite for Mary's holy abstinence.

One of the strangest effects of the antagonistic relationship between appetite and abstinence is the equation of the mouth with the vagina. Although both represent corporeal points of entry, the equation of mouth with vagina remaps the human body. Although both men and women have mouths, only women have vaginas. Thus the male mouth can be mapped as a different location from that of the female mouth. Significantly, the male mouth is often not depicted as a place of eating, but rather as a place from which proceeds wisdom, understanding, and statements of power. The insistence of the Roman Catholic Church on male priests reifies this association. The very name of St John Chrysostom is an excellent example: literally, his name means John, the one with the Golden Tongue. The male mouth is the mouth of God who brought the world into being with his word. But men do not have the power to speak beings into existence. That power resides in the pen/is. The female mouth, however, is mapped as an entrance, or as the opening to a place of darkness into which the fruit that produced sin entered. But the female mouth is also like the womb which births temptation. If one pushes the connection between the mouth and the sexual organs to its end, one arrives at a disturbing conclusion. The male mouth and penis both proceed from the male body. These parts contain and produce power - the penis produces life itself. The female mouth and vagina are only entrances to the female body. These parts tempt men and produce sin. The food that women ingest sustains their sinfulness and produces the suspicious menstrual flow, and in giving birth to children, the womb ultimately produces fallen people, whose end is death.

While this equation treats sexual activity as highly suspect, it fails to acknowledge the accompanying suspicion of food as that which sustains the body - both male and female - in its sinful state. The equation of the female womb and mouth with sin and death ignores the strange body - estranged body - that it creates by placing two different parts in essentially the samé position. It reduces the central human relationship to a contest between sexes.

In addition to being the human location of sinful desire, the fount of sin itself, which brings death into the world, Eve also functions as the purveyor of food, specifically the fruit flesh. She brought the forbidden fruit for Adam to eat. Her daughters, then, prepare food for Adam's sons to eat. But in this role they are ironically suspicious in that they re-enact Eve's offering of the forbidden fruit to Adam even as they serve life-sustaining elements. 
In contrast to Eve, Mary is rarely depicted with food. ${ }^{5}$ Instead, she is always shown with the Christ child, and at most a bare breast, implying that she has nursed him. Occasionally, theologians and artists show her milk sustaining and preserving others too (Warner, 1983, pp. 195-205). The food that she offers to the Christ child is presented as deriving from her holy, virginal body. Mary is most strongly associated with food at Christ's first miracle, for it is she who approaches him to resolve the issue of having run out of wine during the celebratory wedding dinner. In this instance, Mary is clearly associated with the production of food. How else would she be aware that the host of the event had run out of wine? This episode completes Mary's association with traditional female labors - she has given miraculous birth, and she can ask her son to produce miraculous wine. Still the sustenance that Mary produces is not suspicious (perhaps poisonous or sinful), but miraculous, and performed through mediation with Christ himself. Mary thus gains association with holy birth and with holy drink. However, these links leave out flesh. She, unlike Eve, is not associated with flesh. She is not an object of sexual desire. She herself is not the object of the male gaze: she points beyond herself to her son, Christ. To gaze on her is to contemplate salvation, to beg for her intervention.

Not only is Mary's association with food made miraculous, but Mary's voice - heard in heaven pleading for sinners - is the antidote for temptation. Christ will listen to his mother, and those who cannot get help from God, can get help from her to move God's benevolence on their behalf. Her holy voice in prayer to her son leads to the redemption of sinners doomed by Eve, Eve's eating, and the temptation that Eve voiced to Adam. Given that Mary is the model of undisputed holiness for women and given the powerful connection between her and abstinence, one should be unsurprised by the association of holy women not only with fasting, which has a long association with holiness in the Judeo-Christian tradition, but also with silence, except in prayer. For the mouth silent to other humans is closed, and temptation, therefore, cannot proceed from it.

As Christianity spread, women and men could not escape Eve's presence. As Mary and Eve became the polar opposite models for women, two diverging views of women emerged in popular imagination. Women might be like Wealtheow, wife of Hrothgar: she brings peace between Beowulf and Hrothgar's men by serving them wine and by bringing family allegiances along with her when she marries. Although Beowulf is certainly an early text, the $s c \bar{o} p$ clearly links women with food. Good women serve food. Bad women - like Grendel's mother - eat flesh. This 


\section{PROOF}

connection continues into the Middle Ages. Women following after Eve might be like Chaucer's Wife of Bath - sexually aggressive with split front teeth that suggest open legs. The association of her teeth with her sexual availability reinforces the connection between women, food, and sex. Indeed, Dame Alyce clearly enjoys sex: she announces early in the pilgrimage that she has had five husbands and will welcome a sixth, primarily because, she tells her fellow pilgrims, St Paul has determined that it is better to marry than to bum. In addition, Dame Alyce violates the prescription that women be silent. Dame Alyce, who lectures her current husband Jankyn on how to behave, is like Eve. She is sinful; she is not virginal, but sexually active, not silent, but vocal, and the illustration of her in the Ellesmere MS clearly indicates that she enjoys food. She is fat.

A distinct contrast to Dame Alyce, medieval holy women, particularly those in the mystic tradition, often rejected food and sex. These women sought the best position available to them - Bride of Christ. Their desire for salvation and eternal union with the divine beloved produced a tradition. This tradition prized virginity as the most holy state for both men and women, rejecting sex and, in some cases, the body, altogether. ${ }^{6}$ Men could lead holy lives as monks; women could lead holy lives as nuns. But in the cloister or abbey, a third tradition developed, one followed particularly by women, and food played a significant role in it. In the mystic tradition, women desired holy union with Christ, as they hoped to become his spouse. Seeking such union, many women punished their bodies in attempts better to understand Christ's sufferings for the salvation of humankind. ${ }^{7}$ They fasted, claiming that the only food they needed was the Eucharist, and the only drink necessary for living was wine from the chalice. When these women took in the consecrated wine and wafer, they experienced mystical union with Christ himself; some experienced such ecstasy that they fainted. ${ }^{8}$ The belief in transubstantiation, by which means these women ate Christ's flesh and drank his blood, can be interpreted in another way as well. These women sought to be Christ's bride, and given the persistent association of food with sex, they then, in Communion, performed a kind of mystical sexual act, and for such women, the association of food with sex is reinforced. The beliefs and consequent actions of these women indicate the tensions between Eve and Mary as the two models for female behavior and the difficulty they represent for women who desire holiness but recognize that they can be neither Eve nor Mary. 


\section{PROOF}

Take and Eat: Eve, Mary, and Feminist Christianity 113

Although the Protestant Reformation reduced the emphasis on the position of Mary in relation to the Trinity, and although it focused on the importance of individual relationships to God for both men and women, the Reformation and its Roman Catholic counterpart - the Counter-Reformation - did little to change the models offered to women. Women remained daughters of Eve, and Mary epitomized female holiness. Women still faced accusations of tempting men to sin, and the connection between appetite and abstinence remained constant. In the sixteenth century, Anne Boleyn is perhaps the most famous example. Because Henry became enamored of Anne while married to Catherine of Aragon, Anne became the human forbidden fruit, the symbol of the fall itself. Strikingly, the contrast between the two women revolves around both food and fruit (children). Catherine, a notably holy woman, prayed and fasted (Weir, 1991, p. 255).' Her eating habits reinforced her holy reputation. But Henry asked for an annulment based on the assertion that she had been married to his deceased older brother, Arthur. Anne Boleyn, in contrast, had a reputation for enjoying music, dance, and wine (Weir, 1991, p. 153); she fasted only as a means to recover from the sweating sickness (Warnicke, 1989, p. 80). The fact that Henry's giving in to temptation meant divorce from Catherine and separation from the Roman Catholic Church undergirded Anne's position as both Eve and the fruit that represents sin. Once she failed to produce a son for Henry VIII, she faced charges of sexual license and committing adultery with several men, including her brother. Indeed, she was rumored to have attracted Henry's attention through witchcraft (Wamicke, 1989, p. 231; Weir, 1991, p. 304). The tenor of these accusations positions Boleyn as a daughter of Eve, who instead of promoting holiness and salvation by giving birth to a son, produced only disorder and a daughter. In addition, the Roman Catholics who desperately wanted England to acknowledge the authority of the Pope once again, furthered the image of Boleyn as a whore, ${ }^{10}$ equating her with the whore of Babylon in her wooing of a man once awarded the title 'Defender of the Faith' away from the Church.

Shakespeare and other Early Modern writers treat women who fast in order to prove that they are 'chaste and loyal wives' as models, despite the fact that these women 'undertake fasting, fully intending to die.' In contrast, men who fast appear as 'abnormal and unnatural' (Gutierrez, 1992, p.79).11 So, the relationships between characters and food as presented on stage became part of and reflected widespread positions on eating. These attitudes, also visible in Erasmus 
and Elyot, continue the tense relationship between women and food. To prove their chastity and loyalty, women must die by voluntarily giving up food.

References to women and eating during the early modem era suggest continued anxiety over how and what women eat (Lee, 2005, p. 65), and the way in which the use of their mouths might encourage sin. Concomitant with the insistence on women as tempting men to $\sin$, was the insistence on appropriate speech by women. Popular literature on women as shrews and on shrew-taming emphasized the necessity of appropriate speech for women, enjoining them to a life of silence in public and quiet conversation at home.

In Supplement to the Voyage of Bougainville Diderot imagines an encounter in the South Seas with an indigenous family which revolves around contrasting at tudes toward women, food, and sex. In the episode, the Tahitian male offers the European traveler food prepared by his wife. At the end of the meal, the man then offers the traveler his choice of companion for the night: he may choose the man's wife or any one of the three daughters. The youngest daughter begs the traveler to choose and to impregnate her so that she will have the same status in the family as her two sisters who have already given birth (Diderot, 2007, pp. 213-16). Western equations of women, food, and sex underlie any reading of this text. Women prepare and serve the food. Then, they are served to the traveler as a means to satisfy his sexual appetite. But, while the woman prepares, serves, and is served, she does not eat. Her eating is not important. Indeed, the desire that drives the youngest daughter is the desire for a child. And, while he complains that his religion should prevent him from having sexual relations outside the boundaries of marriage, her father's arguments that this natural state is so much better, so much purer, win the day.

In this struggle between Christian beliefs and the idea of the noble savage, the youngest daughter - one of the savages - demonstrates her purity by following the dictates of nature. But she is still the food that will satisfy the sexual appetite of the male. So she is unlike the Christian women whom the traveler has left behind who have opted for Marian chastity. Instead, she is a new kind of Mary: natural, pure, and servile. But this woman is also Eve. Her natural state - perhaps Edenic - is one that tempts the Christianized man to extramarital sex, an activity that has clearly been labeled sin. This pattem repeats the pattem of Eve with Adam. Eve offers Adam food. He eats. He then realizes his nakedness and feels shame. Still, only two positions exist for women to fill: they can be either Diderot's nobly savage women who feed men, then beg 


\section{PROOF}

for sex, or they can be Christianized Europeans who feed men, then virginally refuse sex except in marriage.

In the nineteenth century, women continued to find themselves positioned between these polarities, although the Church exerted less and less influence. Not explicitly Christian, but still asserting JudeoChristian morality, the Victorian image of the Angel of the Hearth certainly bought into these two stereotypes. Indeed, women's difficulties with food became so pronounced that doctors gave one eating pattern a new name, 'anorexia nervosa.' Such abstinence from food was likely related to the need for control (Polinska, 2000, p. 575). But such exaggerated undereating also tapped into a persistent subtext that insisted that desirable, chaste women had to be thin (Michie, 1987, p. 22). For those women who grew round with childbearing - a visible sign of sexual activity - could not be seen publicly. Again, women found themselves inexplicitly positioned between two eating patterns, one associated with Eve-like temptation, the other with Marian virginity.

Despite the continued decline of Church influence on society in the twentieth and twenty-first centuries, women still find themselves between contested ideals of appetite and abstinence. Christians, and members of other religious traditions that promote modesty, continue to struggle with the body, particularly with what constitutes its appropriate use and display. These questions and conflicts ahnost always relate to display of the female body and are often vaunted in the context of images presented by a variety of media. Overall, photographers and filmmakers design images of women, as Mulvey (2007) has ably argued, to satisfy the male gaze. The emphasis is on reifying a particular image one that bears a striking resemblance to the physique of a medieval ascetic mystic who mysteriously survives on morsels of the Host and on the sip of wine from the chalice, or to the chaste, loyal wife who dies by fasting. Accompanying the rejection of a feminine body that this emaciation represents is also a rejection of 'fat' as 'bad,' a moral term that suggests sin. Despite the fact that Western popular culture is argu* ably post-Christian, this kind of thinking clearly has roots in a Christian tradition that positions appetite as evil. The only way for women to achieve the kind of body that the media establish as the ideal, or even as 'healthy,' is to deny appetite itself. Indeed, giving in to appetite has been pathologized as 'bingeing' or 'overeating.'

In a striking reversal of the dichotomy that puts the Virgin Mary on a pedestal and relegates Eve to a pit, it is Eve, with her sexual appetite, who is now applauded as the model for the 'new woman.' The problem is that simply reversing the model does not open any avenue by which women 


\section{PROOF}

\section{Intersections in Christianity and Critical Theory}

can escape from these two polarities. Woman faces the strange mapping of her body in which the vagina is equated with the mouth. The penis becomes a substitute for food, and woman's desire for sex should help her to control her gustatory appetite. The increasing emphasis on achieving health still offers only appetite and abstinence as choices. To reach the accepted state of physical and mental health, the woman must abstain from food, now coded as 'unhealthy eating choices,' and fulfill her appetite for sex. The pervasive nature of this binary model warrants re-examination, for as models for female behavior, Eve and Mary represent unobtainable poles. No living woman will ever claim to be the mother of all persons; nor will any living woman claim to be pregnant without sexual intercourse. Christ will always be male. So, given these parameters, what model is available to women? What place is available for them?

The answer is at the Communion table. For it is at this table that Christ himself took the position designated for women. He serves the disciples his flesh and offers them his blood to drink. Significantly, before this meal he had already equated himself with fully satisfied appetite, and he did so in the context of a conversation with a female outcast. In the well known story of the Woman at the Well, Jesus, who is alone, offers a Samaritan woman 'living water.' He claims that this water will so satisfy her thirst that she will never thirst again. Importantly, her response indicates the pervasive association between women and physical appetite. She calls her friends to meet Jesus because he has promised her water that - she hopes - will keep her from constantly working to satisfy her household. This brief moment evokes other references to Christ as food: the Bread of Life, the Vine. In each case, Christ offers himself as the substitute for the food that Eve and all her daughters prepare and provide.

At the Last Supper and symbolically at Communion, Christ presents himself as the substance of an entire meal. First, he humbles himself to wash the disciples' feet. Then they sit at the table to eat a meal that, very likely, women, their social inferiors, prepared and served. Although the context of the Passover meal had always been that of remembering God's intervention in a specific situation, Christ enlarges the symbolism. Having already positioned himself as a servant, he declares that the blood that he will shed and his broken body, represented in the wine and bread, will bring a different kind of intervention: rather than sustenance for physical flight from physical threat, this meal promises eternal salvation. Christ's command that the disciples eat this meal with 
its eternal symbolism/significance suggests that this instruction TO EAT redeems Eve's earlier, eternally significant violation of the instruction NOT TO EAT. Considered as a redemptive act for Eve and Adam's ingestion of the forbidden fruit, the ritualized lifting of a food and eating taboo not only makes sense as reversal, but also as emancipation of Eve's body from the symbolic cannibalism to which the female body has been subject.

Additionally, the triple insistence of Jesus on his position as servant he washes feet, serves wine, serves bread - repositions women, transforming them into those who are served, rather than those who serve. No one has ever been able successfully to deny women a place at this table.

The very act of taking Communion, an act which necessitates ingestion by the mouth, re-positions the female mouth and redeems it from its symbolic position as the port of sin. Instead of constant association with Eve's mouth and that first taste of the forbidden fruit - the opening from which her voice issued, tempting Adam likewise to eat the forbidden fruit and thereby creating an entrance into the world for sin and death - the female communicant's mouth becomes an entrance for salvation, the force that purifies and gives eternal life. Rather than directing the body to sin, the mouth becomes the salvific member of the body, and the vagina becomes the entrance of fully mapped human beings into the world, those who can, as recipients of felix culpa, experience salvation. Because salvation for both men and women comes from the ingestion of the same substance at the same point in the body, both can claim salvation of language that proceeds from the salvific opening.

Because Communion provides the mnemonic for salvation, appetite for this meal, in contrast to fleshly appetites for forbidden fruits, is divine. For the appetite for salvation can only, according to Augustine, be excited by a profound sense of spiritual lack. And only Christ himself can prompt the sinner to such an appetite. Moreover, sin/flesh or sinful flesh cannot satisfy the appetite for salvation. Attempts to find satiety in sin and flesh only deepen hunger. Sated by salvation, which the conclusion of the Eucharistic meal represents, appetite is itself redeemed. Instead of leading to greater attempts for satisfaction that no one can achieve, using substances that lead only to greater hunger, this appetite continually returns not only to the source of the appetite itself, but also to its eternal satisfaction. In this paradigm, appetite need not be managed or controlled. Nor is abstinence the standard for holy behavior. Instead, appetizing fruit is appropriate fruit, and the command is not to abstain, but to take and eat. 


\section{Notes}

1. Among the first to suggest that women moderate their experiences through male language and ideas was Simone de Beauvoir. Other writers who argue for the difference of women's experiences across the hurnan spectrum are Carol Gilligan, Hélène Cixous, Luce Irigaray, Julia Kristeva, Carolyn Heilbrun, and Gloria Anzalduá. Susan Bordo's work on female body image is also important (Bordo, 2004), as is Horner and Keane's (2000). Of course this list is only partial as many scholars have explored this territory with grace and sophistication, and their work is widely available.

2. Milton's retelling of this story in Paradise Lost is an exception to this statement.

3. Blaumires (1992, p. 3) explains, 'Even Augustine [...] thought woman more than man represented an orientation of the mind towards the material rather than the spiritual. In a cruder form of such thinking, woman becomes bodily sensation.' Blaumires continues to explain the working out of such misogynist thinking: theologian-philosophers conceived of women as 'being[s] who constantly risked sinning almost by [their] very existence, if that existence caused a man to have lustful thoughts.' Moreover, 'not only did women excite men to sinful thoughts; women were actually held to be more lustful creatures by nature. From here it was a short step to the equation, woman equals lust' (ibid., pp. 4, 5).

4. Medieval philosophers posited that women could attain only three levels of perfection, 'with faithful wifehood at the bottom, and chaste widowhood and virginity higher up the scale. [...] though the greatest admiration was inevitably reserved for virgins' (Blaumires, 1992, p. 13).

5. One notable exception is the Virgin with Child by Gerard David and the seemingly popular reproductions of this image in which Mary is shown with Jesus before a table on which are foods for both to eat. The position of the foods suggests that Mary is introducing her child to solid food, an image that reifies Christ's humanity (Tomasik and Vitullo, 2007, p. xx).

6. Although the early Church deemed the rejection of the body total a heresy (Gnosticism), the ascetic tradition, in which mortifications of the flesh were acceptable and encouraged, flourished.

7. Although part of the mystic tradition, anchorites function in an entirely different way. As holy women, they were not sexually available. But these women might live locked in a cell, cared for by passers-by or by those who brought gifts of food. From this position, which restricted food intake and eliminated sexual activity, people expected the anchorite to dispense wisdom and to speak truth. For more on this tradition and its relationship to food, see Bynum (1987).

8. Bynum (1987) explores this aspect of medieval life in great detail. Additional specifics regarding female devotion to the Eucharist appear in Bynum (1991).

9. Significantly, Catherine saw herself following the example of the medieval holy wife, "openly declaring herself to be a "Patient Grizelda"' (Weir, 1991, p. 167), a reference that not only connotes patience, but also thinness and deprivation.

10. Anne's increasing power at Henry's court resulted in several public accusations of whoredom. The Abbot of Whitby was the first in 1532 (Weir, 1991, 
p. 230). Although Anne tried later to publicize her devotional life, her efforts were not enough to reverse the public perception of her as a witch and whore.

11. Significantly Hartle draws attention to the development of the 'Great Eater' subgenre, an outgrowth of the Interregnum. While this gente celebrates particular gourmands, it also draws attention to the conflict between Puritan values that eschewred conspicuous consumption and social practices that valued feasting. Certainly for all, holiness again became associated with fasting, while feasting suggested - for men - 'eccentric' theology. Women heard the association between eating and sin reinforced even in sermons, such as the Sermon against Gluttony and Drunkennesse (Hartle, 2007, pp. 42-3). 